\title{
A MODEL FOR TELECOMMUNICATION TECHNOLOGY TRANSFER AND DIFFUSION INTO THE RURAL AREAS OF SOUTH AFRICA
}

\author{
H.L. Pieterse and M.W. Pretorius \\ Department of Engineering and Technology Management \\ University of Pretoria \\ tinus.pretorius@eng.up.ac.za
}

\begin{abstract}
Telecommunication is one of the keys to sustainable economic development in South Africa. Mobile operators are already reaching people in rural areas without roads, rail or a stable power supply. Telecommunication is also a fast moving high-technology field where technology transfer occurs regularly. Technology transfer is however a complex subject where governmental regulations, social and cultural aspects, needs, expectations, aspirations, financial abilities and technological capabilities play their part. Transfer models that neglect these aspects, often cause ineffective utilisation of technology. Technology transfer between two parties at different hierarchical levels of technology, often occur with limited advantages to the lesser-developed party. A transfer model is needed to improve the transfer process. This research attempts to provide such a model and guidelines.
\end{abstract}

\section{OPSOMMING}

Telekommunikasie is een van die belangrike insette tot voortgesette ekonomiese groei in Suid Afrika. Mobiele telekommunikasieverskaffers voorsien reeds dienste aan mense in afgeleë gebiede sonder paaie, spoornetwerke of stabiele elektrisiteitstoevoer. Telekommunikasie is ' $n$ tegnologies gevorderde veld waar ontwikkeling vinnig plaasvind en tegnologie-oordrag algemeen voorkom. Die oordrag van tegnologie is egter " $n$ komplekse onderwerp wat aspekte soos regulatoriese maatstawwe, sosiale- en kulturele aspekte, behoeftes, verwagtinge, aspirasies, finansiële aspekte en tegnologiese vaardighede insluit. Oordragsmodelle wat nie hierdie aspekte in ag neem nie, lei tot sub-optimale aanwending van die tegnologie. Tegnologie-oordrag tussen partye op verskillende vlakke van tegnologiese vermoë vind dikwels plaas, met beperkte voordeel aan die minder-ontwikkelde party. "n Oordragsmodel is nodig om die oordragsproses te verbeter. Hierdie navorsing het dit ten doel om so ' $\mathrm{n}$ model te verskaf. 


\section{RESEARCH BACKGROUND}

Policy makers and planners must consider technology as an important variable in national development that needs to be modified to satisfy the changing needs of society [1]. Technology transfer can benefit the receiving country in various ways, for example:

- create employment opportunities

- improve quality of life

- prevent economic stagnation

- enhance creativity

- enable the lesser-developed country to become economically more independent.

Only an appropriate technology, when effectively transferred and managed, will have these advantages. Appropriate technology refers to a technology that will make effective use of the lesser-developed country's limited resources and capabilities while being sensitive towards their natural environment and helping them to further develop resources at a minimum social cost [1].

Telecommunication is one of the keys to sustainable development in Africa and South Africa. The sector offers opportunities for indigenous innovation and can assist national development. Access to a telecommunication medium not only serves critical sectors like education, safety and health, but also serves as a stimulant for creating new small businesses and sustainable improved productivity. Telecommunication technologies can create a more productive business environment, as efficiency of business is greater when access to telecommunication services is more reliable [2]. It makes information technology and remote education possible and might improve rural communities' health through creating a better infrastructure for community service doctors and extend their presence. Telecommunications reduce transport costs in lesser-developed countries (radiophones made cost savings of over $60 \%$ possible for two rural factories situated in Bangladesh [3]).

Technology transfer is however a complex subject where governmental regulations, social and cultural aspects, financial abilities and technological capabilities play their part. Technology transfer models that neglect these aspects, often cause ineffective utilisation of the technology. The increased complexity of technology is such that no individual firm or country can hope to satisfy all its needs. Japan and Asia's experience [4] showed that industrial development in the latter half of the twentieth century and beyond has as one of its key requirements the upgrading of technology in production and infrastructure.

\section{RESEARCH PROBLEM}

The objective of the research is to derive a model for telecommunication technology transfer into rural areas and provide guidelines for the improvement of the transfer process. The essence of the problem $\dot{\mathbf{s}}$ how technology should be transferred from one country to another when the transfer takes place at different levels of technological utilisation and know-how. South Africa is in a unique situation where both developed and underdeveloped (rural) sectors exist. Technology transfer currently occurs fairly successful between the developed sector and multinational corporations, after which technology is diffused from the developed sector into the under-developed sector if the necessary precautions are being taken. 
One of the problems is however that technology cannot be transferred successfully from multinational corporations to rural areas without the necessary support. If this is attempted, rural areas have to make use of foreign expertise to implement and maintain the technology because of the absence of skilled local manpower. Telecommunication technology transfer between two parties at different hierarchical levels of technological know-how/utilisation often occurs with limited or no advantages to the lesser-developed country. A transfer model is needed to improve the situation and make technology transfer a process from which both parties can benefit simultaneously. To develop such a model, the research problem holds the following aspects that need investigation:

1. A study of available transfer models, ideas and suggestions for technology transfer between countries at different hierarchical levels of technological know-how, and evaluation of their applicability.

2. Evaluation of the current ability to transfer/diffuse technology from the developed to the under-developed sector and identification of existing technology transfer problems in the South African telecommunication industry (fixed-line \& mobile).

3. Identification of strengths and weaknesses in the technology (knowledge, people and systems) of both the developed and the under-developed sectors to find aspects that might first have to be uplifted before interaction can be successful. (Socio-economic, cultural, educational, technical and environmental conditions are different within different areas).

4. The development of a telecommunication technology transfer/diffusion model for the South African situation with mutual advantages to the under-developed as well as the developed sectors.

\section{A PROPOSED TRANSFER MODEL}

According to Madu [1], some critical factors needed for successful technology transfer include:

- a stable government and political system

- effective and productive management processes

- a high level of education and training

- $\mathrm{R} \& \mathrm{D}$ (inter-firm agreements).

The availability of natural resources is not a necessity for the development of a country but might enhance the development process if managed correctly. Malfunctions in the technology transfer process into lesser-developed countries can be mapped in three different dimensions, namely:

- a structural dimension (different local governments, ethnic groups, government agencies and the private sector)

- a technological dimension (design of equipment, machinery and instruments, data, information and management systems)

- a behavioural dimension (religion, economy, charity and social aspects) 
These dimensions can also be used to characterise a particular country or region. With the generation of a technology transfer model, the questions that need to be answered include: which technology to transfer, how many national resources to devote to each technology type, from where to transfer the particular technology, what is the future of the technology once it is successfully transferred, what are the transferor's and receiver's strengths and weaknesses and how can these be effectively used to transfer technology to the receiver. Five different but complementary technology transfer approaches are:

- a Prescriptive Framework for Technology Transfer

- strategic planning in Technology Transfer

- strategic Planning Dialectical Approach

- a systems approach to the Transfer of Mutually Dependant Technologies

- the Technology Acquisition Hierarchy (TAH).

The proposed technology transfer model is shown in Figure 1. A short discussion of each step within the model follows.

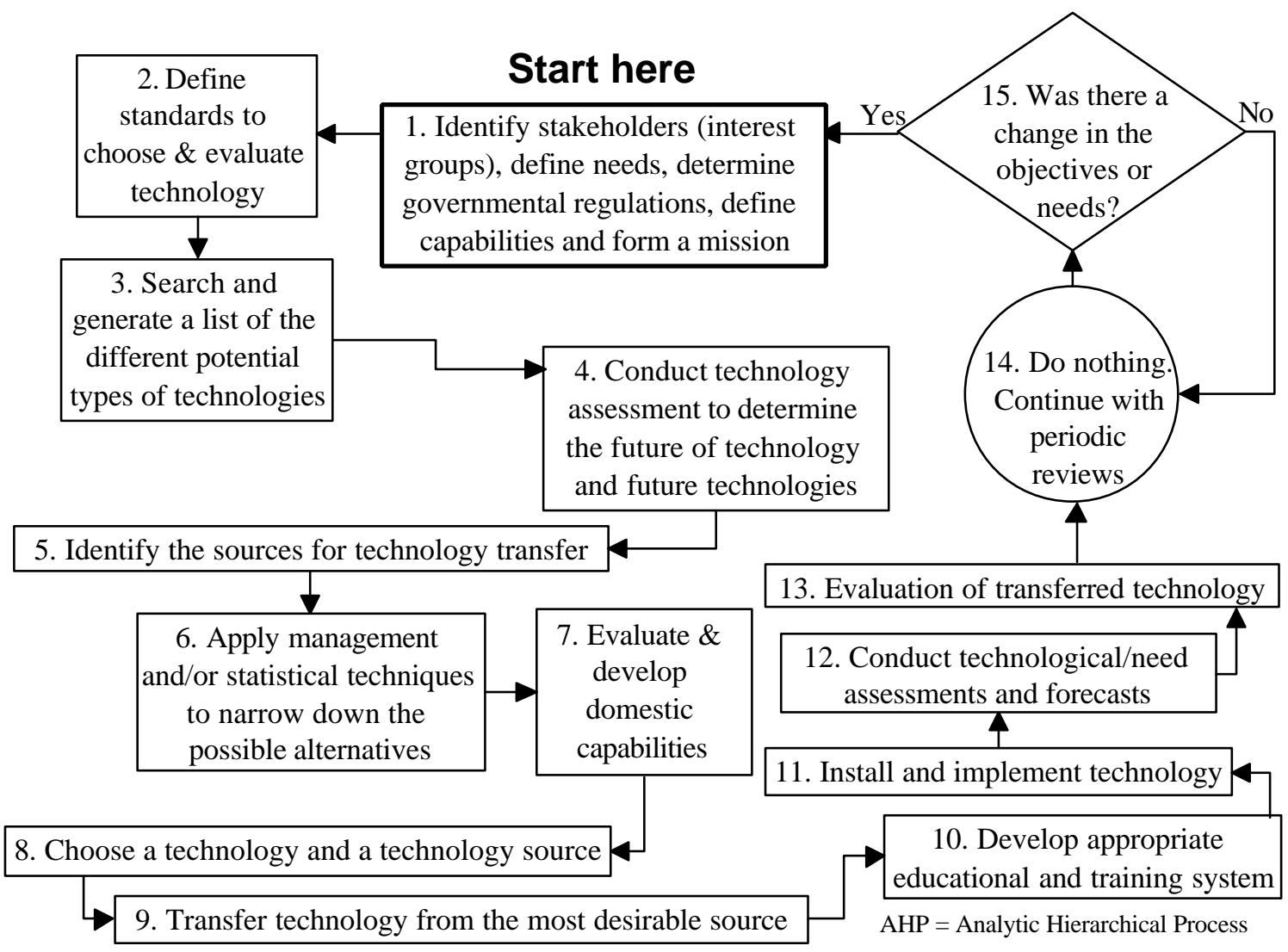

Figure 1. A Model for Telecommunication Technology Transfer/Diffusion Into Rural Areas of South Africa.

3.1 Identify stakeholders (interest groups), define needs, determine governmental regulations, define capabilities and form a mission: The stakeholders are the people directly involved in the technology implementation, people involved in adaptation and modification of the technology, corporate personnel of the receiving telecommunication firm, 
corporate personnel from the technology supporting and supplying firms, the end users and the Governmental regulator. They form a team that evaluates and recommends an appropriate technology to transfer. Stakeholders' views, cultural and social values, backgrounds and needs differ. If these differences are actively integrated into the decision-making process, technology implementation will be enhanced. Only the local stakeholders can truly assess the expectations and aspirations of the people. The stakeholders conduct the development problem definition (a clear outlay of all the factors/problems that limit overall growth/development of the involved country). A Need-Capability Assessment Matrix (a $3 \times 3$ matrix that positions the less developed country in terms of its needs and capabilities for a specific technology) is used to identify strengths and weaknesses and match them to different technologies.

3.2 Define standards to choose $\&$ evaluate technology: Criteria on which a specific technology can be selected are derived from the needs and capabilities determined earlier and can be included in a modified relevance tree diagram.

3.3 Search and generate a list of the different potential types of technologies: Stakeholders search for technologies that will best satisfy the less developed country or region's needs given its capabilities.

3.4 Conduct a technology assessment to determine the maturity of current and emerging technologies: Technology assessment to determine the future of technology requires experience.

3.5 Identify the sources for technology transfer: The receiver should again consider all alternative technology sources and be careful not to build up a business relationship with one technology provider and neglect other alternative technology sources.

3.6 Apply management and/or statistical techniques to narrow down the possible alternatives: Once the lists of alternative technologies and technology sources are generated, the possibilities are often too many to evaluate them one by one. Systematic approaches can be applied and statistical techniques used to narrow down the list.

3.7 Evaluate \& develop domestic capabilities needed for technology utilization: Support (energy provision, information management, maintenance, expansion, adoption, supplier needed inputs) is needed for the transferred technology. It plays an important role in determining to what extend technology can be utilized. Technology space maps, also known as Space-Lifecycle-Hierarchy Maps, are useful to determine supportive capabilities and weaknesses.

3.8 Choose a technology and a technology source: The different technologies should be evaluated and decisions made based on how well it will be able to satisfy issues such as ease of adoption and ability of the less developed country to modify and develop its own technologies. Technologies are evaluated according to its ability to satisfy needs, maximise social welfare, minimising environmental impact, allocate limited resources wisely and minimising the lesser-developed country's dependency on multinational corporations. It is furthermore necessary to establish the input-output relationships between different 
technologies since resources cannot be allocated in terms of priority when interdependency exists. This can be done through the use of an input-output-matrix.

Skills must be developed within the lesser-developed country to adapt technology to local conditions and hardware and software must be modified. If this aspect is not easily achievable, an alternative technology should be considered. In order for a technology to be transferred effectively, the provider and receiver must acknowledge and understand differences in technology (know-how, experience, physical equipment available and use) and plan accordingly.

Stakeholders should identify opposing viewpoints between the objectives of the supplier and the receiver to negotiate conflicting aspects until reasonable compatibility is reached, and develop a joint plan for each technology component (knowledge, people and tools) to transfer the appropriate technology. If such a situation of reasonable compatibility cannot be reached an alternative supplier should be considered. The joint plan should include: training and educational programs for local staff, transfer of the easy accessible accurate information in an understandable language and format, and a modification and installation plan for the needed equipment. It is important that new and old technologies must be able to interface.

3.9 Transfer technology from the nost desirable source: Once the regions are identified and prioritised, the technology can be transferred from the most desirable source.

3.10 Develop appropriate educational and training systems: With effective training and educational systems tailored to meet requirements of the industry (technology acquisition, adaptation and development), the lesser-developed country is better equipped to modify technology for own unique needs. Without effective education they will continue to be largely dependant on the transferor to supply the right labour force, conduct technological innovations and engage in research and development. On-the-job training, in-house training, seminars and tuition reimbursements plans should also be carried out to keep the workers abreast of technological changes.

3.11 Install and implement technology: Considerable time and resources should be allocated towards solving the problem of uninformed users. The users' level of knowledge on existing technologies should be determined after which users should be introduced and trained to use new products and services to their advantage while continuously providing technical support and information inquiry systems. Implementation furthermore involves: obtaining the latest information available on the technology's hardware and software, training local staff, modifying technology to interface with local conditions/existing technologies and an arrangement with the technology supplier to obtain software updates as well as troubleshooting support.

3.12 Conduct technological/need assessments and forecasts: An important element in the technology transfer process is the capability to perform systematic technological forecasting. Maintaining a logbook for the purpose of technology forecasting is often an effective way of doing data collection. Several authors have presented useful techniques, such as technological progress functions (S-curves), trend extrapolation, military trend lagging, the Delphi method and scenario development, see Wheelwright and Makridakis [5]. 
3.13 - 3.15 Evaluation of transferred technology and reevaluation of objectives and needs: Stakeholders continuously determine whether the transferred technology is still meeting standards to achieve wanted outcomes. If not, the technology might have become unsuited for meeting unchanged development needs and it should be modified, or new technology developed/transferred. The cause of the problem might also lie in changed objectives as needs are connected to the dynamic human factor. In such a case, the needs should be re-evaluated and the transferred technology evaluated on ability to be modified to suit new needs. If this is impossible, a new technology should either be developed or transfer. Whenever a technology is modified, an impact analysis should be performed on aspects involving end-users to inform them accordingly before implementation.

\section{RESEARCH DESIGN}

The research was divided into two separate but interdependent phases. First, a survey was conducted with corporate personnel of the telecommunication firms of South Africa (Telkom, Vodacom and MTN). This part of the research was done through questionnaires and interviews. A formal research design approach was not followed for the first part of the research because the research targets were already defined with one representative from each.

The second part of the research was conducted in a South African rural area. This was done to determine the current telecommunication technology utilization situation in underdeveloped areas, and served as an evaluation of needs and a gathering on information about rural citizens' expectations and aspirations. As information in South Africa is available at magisterial district level, this was also used to divide South Africa into researchable regions. Regions were then prioritised on the bases of a survey done in Costa Rica [3] (income, level of education and population density). The criteria have been applied to the underdeveloped areas (regions with no/limited cellphone coverage).

On the basis of the criterion described above, Sekhukhuneland and Mokerong was indicated as regions that might benefit most from the research. Sekhukhuneland was selected as the district for evaluation because of a smaller geographical size making research easier and less expensive. Sekhukhuneland is located in the Northern province of South Africa with an average household expenditure of R1 400 and a population of 414790 people consisting of 99.09\% Black, 0.04\% Coloured, 0.002\% Indian/Asian and 0.13\% White people.

Simple random sampling, the basic sampling design, often provides good estimates of population quantities at low cost. Very little information is available on the different groups (e.g. urban and rural) that exist within the district. When stratified sampling wants to be used, it is almost impossible to assure that a non-overlapping group is defined because of the freedom to move around. Perfect simple random sampling is almost impossible (and financially non-viable) to conduct within a population size of 414790 . Thus, an approximate simple random sampling technique was used (a convenience sample that is taken with the aim to cover the whole spectrum of people when considering their level of education).

For this survey, the level of education was seen as the most important determinant to benefit from telephony (income correlated to level of education). Education was thus used as the main criterion for evaluation. The population's level of education lies within the range from 0 
to 24 years. The error was taken to be 6 months or $1 / 2$ a year $(2.083 \%)$ that yielded a sample size of 256 .

The number of questionnaires was divided into groups of educational level to cover the whole spectrum as indicated by the Statistical Department of South Africa. Questionnaires were designed to test certain aspects of rural South Africa on the basis of the telecommunication technology transfer model described above. Qualified personnel conducted 258 interviews over a period of 10 days during July 2001.

\section{FINDINGS}

In Sekhukhuneland only $43 \%$ of the population is employed with an average household income found to be R 1492.61 per month in households with 6 people on average (thus average per-capita-monthly-income is R260.55). A significant proportion (38.76\%) of the population have never been through any official education. $28.86 \%$ of the population have acquired primary school education, $16.67 \%$ secondary school education up to Gr10, $11.63 \%$ secondary school education between Gr10 and Gr12, while only $3.49 \%$ of the population have attended any post-school studies.

The current suggested plan for South Africa involves two separate paths that should be followed in parallel as indicated in Figure 2 (dotted line block).

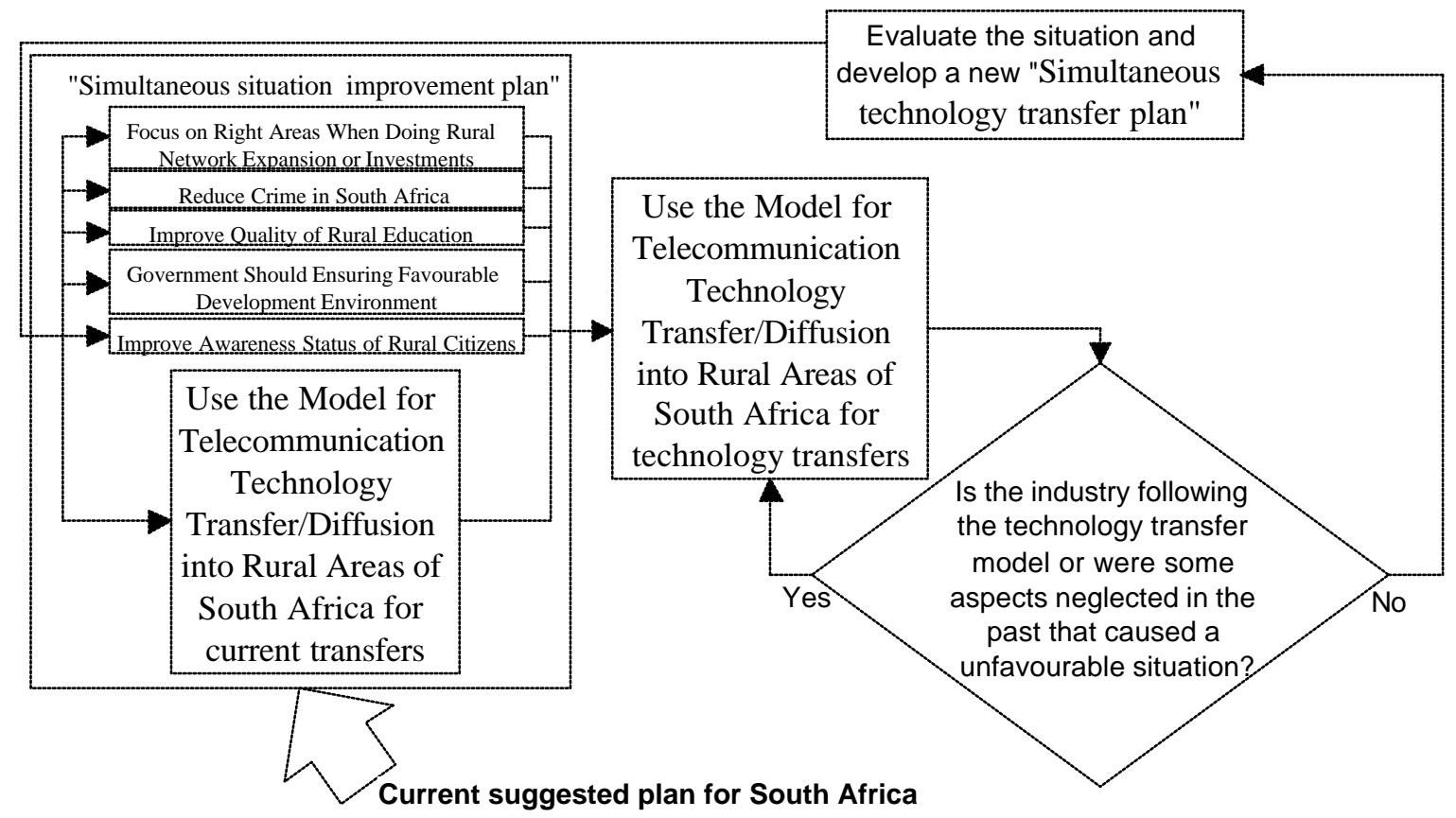

Figure 2. Strategy for improving the current situation of the telecommunications in South Africa

The simultaneous-situation-improvement-plan involves five parts. First, the industry should focus on the right areas when doing rural network expansion or investments. Results showed that one could, on the basis of the different economic and social characteristics of citizens (villages' average level of education and monthly per capita income) prioritise them to maximise the potential benefit it might hold. Villages with a high potential to benefit should 
be placed high on a priority list for new rural network investments. A Chi-Square value of 0.0485 shows statistic significance (Chi-Square $<0.05$ ) between the level of education and the characteristic of an individual to dislike the idea of owning a personal telephone or cellphone. A Chi-Square probability value of 0.0060 and 0.0001 was found when examining the relationship between level of education and owning a telephone or a cellphone respectively. This means that the probability of someone owning a personal telephone or a cellphone in a specific region increase as his or her level of education increase.

Chi-Square probabilities also indicated statistical significance $(0.0017)$ when comparing per capita income to a need for telecommunication (fixed-line and mobile). A Chi-Square probability value of 0.0001 , shows owning a cellphone depends highly on ones per capita monthly income but a value of 0.2513 indicates no statistical significance between owning a fixed-line telephone and income (per capita). The reason for this phenomenon is twofold: Governmental regulations forces Telkom to install land lines without examination of affordability and many rural citizens are not adequately informed on the call costs and prefer cellphones.

Only $3.10 \%$ of the population knows the cost of both a fixed line telephone call and a cellphone call. While only $9.69 \%$ of the population knows the cost of a fixed line telephone call, $44.19 \%$ complained. For cellphones, $8.53 \%$ of the population is informed and again a bigger percentage (20.16\%) complains about cellphone call costs, giving call costs as a reason for not having a cellphone. Many rural citizens are under the impression that cellphone costs are cheaper than fixed line call costs, which is incorrect. The main reason is because of Vodacom's Community Phone shops (Vodacom's public telephones) where calls cost $70 \mathrm{c} / \mathrm{minute}$.

Second, the rural citizens' awareness needs to be improved. Of the population who was formerly confronted with an emergency situation, 25\% didn't know the police's number. Only in $4.08 \%$ of the cases was no access to a working telephone given as an excuse not being able to contact emergency services. The situation in the mobile phone industry is even worse. While the emergency 112-service can have many advantages to the rural citizen, only $4.11 \%$ of the MTN customers and $16.44 \%$ of the Vodacom customers were aware of the service and its benefits.

Despite advantages Telkom offers in new products, many rural citizens are poorly (or not at all) informed. Only $31 \%$ of the population are informed about Telkom's prepaid telephone service and only $10 \%$ of the telephone owning population was making use of it. The information diffusion into the rural area for Phonecards was an exception and done extremely successful having $72.87 \%$ of the population being familiar with the product and its advantages. For other products (Homefree, BlockCall, Call Answer and WorldCall [6]) less than $6.20 \%$ were informed.

Of the rural population owning cellphones, $34.25 \%$ are completely uninformed about SMS (Short Message Service), 35.62\% never used the service because of not knowing or understanding how and only $28.77 \%$ of cellphone owning citizens are benefiting.

In Sekhukhuneland, $49 \%$ of the population own bank accounts. Buying airtime for a prepaid cellphone is now also possible using bankcards together with an ATM (Automatic Teller 
Machine). All cellphone owners in the rural areas also own bank accounts from which $60.27 \%$ owns prepaid cellphones. Out of this group, only $2.27 \%$ has ever used their bankcard to purchase airtime.

Many rural citizens (52.94\%) are furthermore ill informed about battery charging procedures and shorten their batteries' life by charging incorrectly. This limits the utilization of technology over time and shortens its lifespan. Knowledge on repairing a cellphone is also a problem: $50.39 \%$ knows where to repair a cellphone, $35.94 \%$ are uninformed and $13.67 \%$ are under the impression that a broken cellphone can't be repaired This means that $13.67 \%$ of the population will dispose of a cellphone when a technical failure occurs and often terminate the use of their cellphones because of financial abilities. This shortens the effective usable period of a cellphone.

Knowledge of the rural citizen can and is currently hindering telecommunication technology utilization for the end-user as well as the fixed-line and mobile service providers. Rural telecommunication will never be effectively operated without active "hands-on" awareness campaigns and the industry is cutting it's own throat by not supplying adequate attention in this matter.

To inform people, the selected language and medium plays a critical role. Depending on the area, the information should be supplied in the appropriate language. $75.58 \%$ of the people living in rural South Africa own a radio and this might be the most effective media for informing people. Because many $(34.88 \%)$ of the rural citizens cannot read, media like newspapers, posters, magazines and information flyers' effectiveness are limited. Affordability (income) also limits the effectiveness of a television set.

\section{CONCLUSION}

The telecommunications industry is covering many of the aspects highlighted in the technology transfer model and technologies are currently transferred to South Africa fairly satisfactory. However, many areas still exist where much can be done to make it more effective and more rewarding to society as well as the industry. The government also has a vital role to play to ensure sustainable growth and to allow telecommunications to play its part in national development.

\section{REFERENCES}

[1] Madu C N, 1992. Strategic Planning in Technology Transfer to Less Developed countries. Quorum, New York.

[2] Carbonell J-L C, 1997. Information and telecommunication technologies for development in Sub-Saharan Africa. University of Pretoria, Pretoria, South Africa.

[3] Saunders R J, Warford J J, Wellenius B, 1983. Telecommunication and Economic Development. A World Bank Publication, The Johns Hopkins University Press, Baltimore and London.

[4] Kaplinsky and Raphael, Edited by Chatterji, Manas, 1990. Technology Transfer in the Developing Countries: Technology Transfer, Adoption and Generation. St. Martin's Press, New York. 
[5] Wheelwright S C and Makridakis S, 1998. Forecasting Methods for Management, $5^{\text {th }}$ edition, New York, Wiley-Inter-science.

[6] http://www.telkom.co.za/consumer/products 